that before all other cities, and above all other places, Glasgow is the city and the place for a statue of Lord Kelvin. Men like Lord Kelvin were seldom solitary voyagers, but rather leaders of a great company of thinkers and experimenters labouring to lighten the burden of suffering humanity. As a practical inventor as well as a thinker his claims appealed to all, and would continue to do so. It was therefore with pride and joy and confidence that he asked the City of Glasgow, for all time to come, to take good care of a beautiful memorial of a truly memorable man.

Principal Sir Donald MacAlister, in moving a vote of thanks to Mr. Birrell, said that the Lord Rector had performed the ceremony with his accustomed felicity, and had worthily expressed the homage of the city and University to one of its brightest ornaments. In the name of the subscribers, Prof. S. P. Thompson moved a vote of thanks to the sculptor; this was seconded by Prof. Perry, and Mr. Shannan replied.

At the luncheon following on the unveiling of the statue to Lord Kelvin the toast, "The Memory of Lord Kelvin,"was proposed by the Rt. Hon. Arthur James. Balfour, M.P.

Mr. Balfour dwelt upon Lord Kelvin's happy combination of great gifts, making him at once the greatest master of theory and a leading spirit in every department of practical affairs. His services to mankind, as man of business, inventor, teacher, investigator of the great problems of the universe, in order more and more to raise the material condition of mankind, rank him as greatest of the great group of physicists who have paved the way for the scientific revolution in the midst of which we are living. Lord Kelvin's want of sympathy with those latter-day speculations to which his own labours led up was not the imperviousness to ideas which comes of mental inertia. But what he would accept from other men depended at the moment upon the intense inner life that he led, which concentrated his attention upon certain lines of investigation, and made him almost oblivious of what was going on outside the current of his own thought. Great in knowledge, great in achievement, yet in himself the most modest, the most eager, the most childlike-in the good sense of the word-of men, his record had never been surpassed in the whole annals of physical science.

\section{THE PREHISTORIC SOCIETY OF EAST ANGLIA.}

THE members of the Prehistoric Society of East Anglia are to be congratulated on the systematic manner in which they are studying the properties of flint, with special reference to the identification of human workmanship. In the latest part of their proceeding ${ }^{1}$ Dr. W. Allen Sturge discussess the patina of flint implements, and concludes that it is produced entirely by exposure on the surface. Permanent burial appears not only to retard, but even to prevent, patination.

1 Proceedings of the Prehistnric Society of East Anglia, 19to-11, 1911-12, vol. i., pt. ii. (I ondon: H. K. Levis, rorz.)

NO. 2294, VOL. 92$]$
Mr. J. Reid Moir describes some experiments on the chipping of flints, and attempts to show that the flaking of a margin by natural causes is comparatively irregular, while the blows directed by man to produce such flaking are at definite angles with much regularity. He also demonstrates that flakes produced by natural pressure often exhibit a bulb at each end. Mr. F. N. Haward follows with additional notes on the chipping of flints by natural agencies, and concludes that much can be accounted for by movements in the ground. He instances particularly the chipping due to the creeping motion of gravel at the top of pipes in the chalk.

Among descriptive papers may be pecially mentioned that by Mr. J. Reid Moir on the muchdiscussed human skeleton discovered by him in a glacial deposit at Ipswich. Though interesting, it is by no means convincing in its argument that the skeleton lay in undisturbed ground; and the difficulty in believing that the human being in question lived before the deposition of the boulder clay is further enhanced by the report if Prof. A. Keith, who finds that there is no cssential difference between this skeleton and thist of a modern civilised man.

There may also be differences of opinion about the supposed flint implements, described by $\mathrm{Mr}$. W. G. Clarke, from the basement bed of the Norwich Crag, in Norfolk; but Dr. Sturge's elaborate paper on Mousterian and other late Palæolithic flint implements from suyerficial deposits in East Anglia will be accepted without hesitation, and is all the more welcome from the abundance of French specimens which the author is able to select for comparison from his own cabinet. All the papers are well illustrated, but this one by Dr. Sturge especially so; and the only fault we have to find with them is their frequent diffuseness. A more concise and systematic mode of expression might be adopted in future with advantage.

\section{NOTES.}

AN extra meeting of the Chemical Society will be held at Burlington House, Piccadilly, W., on Thursday, October 23 , at 8.30 p.m., when the Ladenburg Nemorial Lecture will be delivered by Prof. F. Stanley Kipping, F.R.S.

A LECTURE will be given under the auspices of the Swedenborg Society at the rooms of the Soriety of British Artists, Suffolk Street, on the evening of November 19, by Prof. W. B. Bottomley, of King's College, London, on Swedenborg's doctrine of the origin of life. Sir W. F. Barrett, F.R.S., will occupy the chair.

THE High Commissioner of the Federated Malay States has notified that, in consideration of the importance of the London School of Tropical Medicine to the Government, a sum of $5000 l$. has been voted as a contribution to Mr. Austen Chamberlain's appisal for Ioo, oool. for the endowment of the school. The grant was made by the Legislative Council on the repre- 